\title{
LOCAL TEXT OF A PROVINCIAL TOWN IN INTERNET FOLKLORE
}

\author{
Tatiana Zolotova ${ }^{1}$ and Natalia Efimova ${ }^{2 \star}$ \\ ${ }^{1}$ Prof. Dr., Mari State University, Russian Federation, zolotova_tatiana@mail.ru \\ ${ }^{2}$ Assist. Prof. Dr., Mari State University, Mari State University, nordragon@mail.ru \\ ${ }^{*}$ Corresponding author
}

\begin{abstract}
In the given paper the authors suggest a peculiar way of studying the 'local text' of a town on the material of the Internet folklore created by local population. Any town has an oral history reflected in residents' folklore both in its traditional and contemporary forms. To the latter the authors refer such genres of the Internet folklore as memes, gifs, and demotivators that are posted by a city's residents on public pages of social networking services. The above-mentioned genres have not been studied properly yet, especially in the aspect of their contribution to the issue of urban folklore and local text. The issue of the local text is an important matter in modern anthropology and folklore studies.

The given paper is based on the material concerning the local text of the town of Yoshkar-Ola (Russian Federation), a provincial town but still a unique one in a variety of aspects. The authors have been monitoring the contents of the public page called Typical Yoshkar-Ola located on the popular Russian social networking service VKontakte and have made a collection of 343 memes revealing this or that aspect of the city life. Overall, the analysis of this collection displays a vivid picture of citizens' concerns and perception of the hometown. In the paper some elements of the local text (experience of feeling provincial, citizens' reaction to construction works in the town, to the city's routine and current problems, etc.) are revealed and important observations over the pragmatics and semantics of memes and gifs are presented.
\end{abstract}

Keywords: Yoshkar-Ola, local text, provinciality, social networking services, meme, Internet-folklore.

\section{INTRODUCTION}

In recent years anthropologists and folklorists have become increasingly interested in the so-called urban text. The current literature on this issue suggests a variety of ideas as to how urban text can be regarded. Drannikova and Razumova (2010, p. 15) state it can be defined as a scope of ideas and values typical of a given settlement and community; Zolotova (2006, p. 4) describes it as a synthesis of verbal codes of a city's communities. In the 2012 study, Alekseevsky considers urban text to be a city's image created deliberately or spontaneously. We suggest that urban text is similar to the so-called local text (Efimova 2016) defined by Lurie (2008, p. 213) as a unity of 'settled positions of objects, stereotypical statements, explanatory models, narrative motives and plots, mental and speech clichés which take place in a local cultural tradition and which have helped the local community to build an image of this place, to characterize its temporal, spatial and axiological parameters". Our research is aimed at examining the local text of the town of Yoshkar-Ola 
IJASOS- International E-Journal of Advances in Social Sciences, Vol. III, Issue 7, April 2017

(Russia) on the material of its townspeople's Internet folklore. The research has been conducted since May 2016 and some interim results have come out by the present moment.

\section{MATERIALS AND METHODS}

The data for this study came from a public page hosted by the most popular Russian social networking service VKontakte (VK). The page's name is Typical Yoshkar-Ola; it has as many as 66,000 followers (the data of November 2016). We found about 300 memes and more than 800 humorous photos referred to a specific genre of curious thing (kuryoz) by Klubkov (2000) on the "wall" of the page and in its archives, as well as a small number of gifs (See: Typical Yoshkar-Ola. Public page. Online. Available: https://vk.com/albums-32830117). All the samples were studied from the aspect of their contribution to the city's image and certain perception of the given image.

\section{RESULTS AND DISCUSSION}

Participants of the group (page) Typical Yoshkar-Ola post graphical materials mostly in special albums though single photos and memes can be found in the common discussion thread on the "wall". Photos are more numerous than memes. The latter are defined by Alekseevsky (2012) as a "unit of information (word, phrase, visual image, plot) that spreads on the Internet like a virus gaining popularity in no time and is used actively in everyday Internet communication". As we see it, the reason for photos with captions outnumbering memes is the fact that most of the page's followers are not digital natives and are not knowledgeable enough in technology, i.e. in ways of creating memes, demotivators or gifs. However, we tend to stress the significance of memes in creating the city's local text. The given genre combines text and picture (often a photo or a part of it); it may contain several parts (up to four similar to a comic strip) or even portray a witness of the situation described (often a troll face, some popular politicians, Jackie Chan, Nicolas Cage, Freddie Mercury, Bruce Lee, Yao Ming, etc.). Due to the abovementioned peculiarities, semantics of such works is clearly perceived. This type of Internet folklore reveals problems townspeople are anxious about, possible solutions, meaningful events; it also points to significant places and people. On the whole, memes state facts that promote Yoshkar-Ola's people's feeling of local identity. Consequently, Lurie (2014) refers to such facts as symbols of local identity.

Among the given symbols, one's feeling of provinciality should be thoroughly examined. Considerable research attention has already been paid to it and the phenomenon of provinciality is described by Tihomirov (2010, p. 115) as "a painful experience of perceiving one's separation from big city life, lack of social and cultural resources, life perspectives concerning promotion, education, communication and leisure". Few attempts have been made to investigate the phenomenon of provincialism in Yoshkar-Ola. However, separate facts of Yoshkar-Ola's local text observable in the zero years and earlier are introduced by the authors of $A$ Short illustrated dictionary of clichés and stereotypes (2009, pp. 60-61) in the article about Yoshkar-Ola where the town's provincialism is described as a generally accepted truth, "In Russian before the revolution Tsarevokokshaisk (Yoshkar-Ola's historical name) was similar to modern Uryupinsk, i.e. it stood for provincial remoteness and served as an illustrative example of a godforsaken place". Further, to prove the point, a number of quotations from Russian classical literature and modern movies are given. The authors of the article (2009, p.61) managed to foretell the correct tendencies that emerged well before the great construction works of the present, i.e. the city's attempts to overcome its provincial reputation rooted in its townspeople's mind (in Soviet times Yoshkar-Ola had a nickname of Yoshkar-hole that clearly reveals people's attitude to the hometown). "The fight against provincialism is held on the official level by means of mass media and nonfiction on history where they try to contest pre-revolutionary ideas about the city's backwardness" (2009, p. 60).

The problem of provinciality is raised in the group Typical Yoshkar-Ola regularly both in a conditionally oral form of Internet folklore (memes of specific content) and in followers' everyday communication. Yoshkar-Ola presently takes a peculiar place among other Russian cities. On the one hand, there are numerous attempts of the city's administration and mass media to make Yoshkar-Ola a new tourist and sports center of the Volga region. On the other hand, there are a number of unsolved problems of infrastructure, paving and glaring geographic and cultural isolation in the pre-Internet epoch. No wonder, followers' attitudes to the city's changes are controversial. There emerge memes that claim Yoshkar-Ola's remoteness. The text further establishes the replying interlocutor's indignation because the city is compared to a village: "YoshkarOla? Is that a village? - Say that again!" In the second example it is stated that one always has to explain where the city is situated: "I'm from Yoshkar-Ola / It is next to Kazan". The name of the city itself misleads the listener as originally it is not in Russian and people often consider the city to be situated in the Asian part of Russia or even to be a foreign city: "Yoshkar-Ola? / No, never heard that". "Have you heard about 
Yoshkar-Ola? - Just once or twice in a comedy show". The latter example reflects several facts when the name of Yoshkar-Ola was heard in different comedy shows or movies. On the other hand, there are memes that embody friendly humor towards the hometown, or love: "East or west home is best" (on the background of the city's site), "Tagil city ruuules! / Did I take you right? / Just joking! Yoshkar-Ola forever!"

The city's provinciality is implicitly reflected in works pointing to lack of privacy: "You've gone out/ This face is familiar / That one is, too/ Yoshkar-Ola - that can't be helped"; "Living in a small town means everyone knows you before they've met you"; "Why is my boyfriend / my girlfriend's ex and her ex is my sister's new boyfriend and my sister is my ex -boyfriend's lover? / It is Yoshkar-Ola, babe". The fact that the assortment of goods is not that large as one expects it: "Bought a jacket / Half the city is wearing the same". Some texts state negative sides and stereotypes of young people's entertainment: "You go for a walk in the evening / On Chavain boulevard they are drinking/ On the embankment they are drinking/ Savages!", or state the lack of entertainment: "Why did you come home at 5 a.m.? / It's not my fault that there is nowhere to go in Yoshkar-Ola at 5 a.m.!"

It is necessary to note that the abovementioned situations are typical of memes created by townsfolk of other cities. Thus, in his 2012 study, Alekseevsky quotes similar texts and images in the Internet folklore of the town of Galich.

No doubt, experience of feeling provincial is not the only symbol of local identity of Yoshkar-Ola's citizens. The history and modern city's life give birth to a great number of cheerful or controversial events imprinted in the new pseudo-oral tradition of the Internet. To them we would refer people's perception of the city's changing image that takes place due to great construction works and building replicas of the famous world's sites in the city center, interesting monuments and sculptures, churches, opening and closing of large shopping centers, discussion of roads in the city, administration's decisions, etc. For the current paper is aimed at examining mostly the local text of Yoshkar-Ola town as of a provincial town, we will not focus on other observations here.

\section{CONCLUSION}

On the whole, visual memes of the public page Typical Yoshkar-Ola are an important part of the local text of a contemporary provincial town and help to find out residents' symbols of local identity. Within the given article only one of them is studied - the experience of feeling provincial that has already been stated by other researchers (Veselova 2009). The Internet folklore of the followers of the page Typical Yoshkar-Ola reveals the phenomenon of provinciality via stating closeness of social contacts, imperfections of infrastructure, limited entertainments, isolation, and tendency to memorize unique moments of the town's fame, everyday problems. The genre of visual meme is the most illustrative in this aspect. It is the meme that highlights the city's most peculiar features through the usage of popular Internet characters and their dialogues.

The text of the city in the Internet folklore is formed spontaneously and does not depend on an official point of view or demands of tourism.

\section{ACKNOWLEDGEMENT}

This research was financially supported by the Russian Foundation for Basic Research (RFBR) (Grant NO 16-14-12005).

\section{REFERENCE LIST}

Alekseevsky, M.D. (2012). It's Galich, babe! Local text of a town in visual Internet memes. In Word and Picture. XX Lotman's readings. European University of St.Petersburg. Available at: https://www.youtube.com/watch?v=NuVwMNS0Oo8 (accessed 17.08.2016). (In Russian)

Efimova, N.I. (2016). Internet folklore of fandoms and local communities. In T.A. Zolotova, N.I. Efimova, E.A. Plotnikova, Modern culture of modern youth: a monograph (pp. 8 -63). Yoshkar-Ola.: Mari State University. (In Russian)

Drannikova, N.V., Razumova, I.A. (2010). Historical town in modern folklore. In M.D. Alekseevsky, V.E. Dobrovolskaya, A.B. Ippolitova (Eds.), Slavic traditional culture and modern world. Issue 3. Traditional culture of the modern town (pp. 9-27). M.: State Republican Centre of Russian Folklore. (In Russian)

Klubkov, P.A. (2000). Urban toponymy and folklore. In M.L. Lurye (Ed.), Tradition in folklore and literature: 
articles, publications by teachers and students of St. Petersburg State Academic Gymnasium (pp. 7782).

St. Petersburg: St. Petersburg State University. (In Russian)

Lurie M.D. (2008). Local text of a town and its dictionary description. In Dictionary of local text as a method of describing an urban cultural tradition (pp. 196-198). St. Petersburg: European University. (In Russian)

Lurie, M.L. (2014). Urban local narration. A lecture in European University. Available at: https://www.youtube.com/watch?v=zvrSSLOAclA (accessed 1.09.2016). (In Russian)

Tihomirov, C.A. (2010). Axiology of urban space in folklore of modern young people. In M.D. Alekseevsky, V.E. Dobrovolskaya, A.B. Ippolitova (Eds.), Slavic traditional culture and modern world. Issue 3. Traditional culture of the modern town (pp. 112-125). M.: State Republican Centre of Russian Folklore. (In Russian)

Veselova, A.Y., (2009). Yoshkar-Ola. In Short illustrative dictionary of clichés and stereotypes: to 60-th anniversary of P.A. Klubkov (pp. 59-61). St. Petersburg: Institute of logic. (In Russian).

Zolotova, T.A. (2006). Conclusions. In T.A. Zolotova, I.M. Abramzon, A.V. Abukayeva, N.I. Efimova, V.P. Rukomoinikova, The picture of the world in youth culture of Mari El Republic (pp. 161-163). YoshkarOla: Mari State University. (In Russian) 